\title{
Economic analysis of the inclusion of thermoelectric ash in asphalt mixtures
}

\author{
Análise econômica da inclusão de cinza de termelétrica em misturas asfálticas \\ Análisis económico de la inclusión de cenizas termoeléctricas en mezclas asfálticas
}

Received: 07/22/2021 | Reviewed: 07/26/2021 | Accept: 07/28/2021 | Published: 08/04/2021

\author{
Igor Nonato Almeida Pereira \\ ORCID: https://orcid.org/0000-0002-0238-4242 \\ Federal University of Amazonas, Brazil \\ E-mail: igornonato2010@hotmail.com \\ Newton Paulo de Souza Falcão \\ ORCID: https://orcid.org/0000-0001-5579-0861 \\ National Institute for Amazonian Research, Brazil \\ E-mail: nfalcao@inpa.gov.br \\ Consuelo Alves da Frota \\ ORCID: https://orcid.org/0000-0002-1766-2823 \\ Federal University of Amazonas, Brazil \\ E-mail: cafrota@ufam.edu.br
}

\begin{abstract}
The replacement of conventional materials used in hot asphalt mixtures with others of good technique and lower cost and environmental impact has motivated research in this area of knowledge in recent decades. The researches should be expanded in the scope of engineering, given that it contributes considerably to the transformation of spaces and raw material. In this context, thermoelectric ashes, which are residues from the production of electric energy, appear as an alternative to replace the stone powder input which contributes negatively to the environment considering that it comes from the blasting of rocks. This work aims to compare the cost of producing traditional asphalt concrete (reference) to asphalt compositions containing $5,15 \%$ of alternative material characterized by stone dust. There was a saving of R $\$ 0.21$ per ton of AC machining, consisting of thermoelectric ash as a partial substitute $(5.15 \%)$ for stone powder, which represents significant savings in a practical context.
\end{abstract}

Keywords: Asphalt mixtures; Thermoelectric ash; Economic viability.

\section{Resumo}

A substituição de materiais convencionais utilizados em misturas asfálticas a quente por outros de boa técnica e menor custo e impacto ambiental tem motivado pesquisas nesta área do conhecimento nas últimas décadas. As pesquisas devem ser ampliadas no âmbito da engenharia, visto que ela contribui consideravelmente para a transformação dos espaços e da matéria-prima. Nesse contexto, as cinzas termelétricas, que são resíduos da produção de energia elétrica, surgem como uma alternativa para substituir o pó de pedra que contribui negativamente para o meio ambiente por ser proveniente do desmonte de rochas. Este trabalho tem como objetivo comparar o custo de produção de concreto asfáltico tradicional (referência) com composições asfálticas contendo 5,15\% de material alternativo caracterizado por pó de pedra. Houve uma economia de $\mathrm{R} \$ 0,21$ por tonelada de usinagem AC, composta pela cinza termelétrica em substituição parcial $(5,15 \%)$ do pó de pedra, o que representa uma economia significativa na prática.

Palavras-chave: Misturas asfálticas; Cinzas de termoelétricas; Viabilidade Econômica.

\section{Resumen}

La sustitución de materiales convencionales utilizados en mezclas asfálticas calientes por otros de buena técnica y de menor costo e impacto ambiental ha motivado la investigación en esta área del conocimiento en las últimas décadas. Las investigaciones deben ampliarse en el ámbito de la ingeniería, dado que contribuye considerablemente a la transformación de espacios y materia prima. En este contexto, las cenizas termoeléctricas, que son residuos de la producción de energía eléctrica, aparecen como una alternativa para reemplazar el aporte de polvo de piedra que contribuye negativamente al medio ambiente considerando que proviene de la voladura de rocas. Este trabajo tiene como objetivo comparar el costo de producción de hormigón asfáltico tradicional (referencia) con composiciones asfálticas que contienen un $5,15 \%$ de material alternativo caracterizado por polvo de piedra. Hubo un ahorro de R \$ 0,21 por tonelada de mecanizado de CA, consistente en ceniza termoeléctrica como sustituto parcial $(5,15 \%)$ del polvo de piedra, lo que representa un ahorro significativo en un contexto práctico.

Palabras clave: Mezclas asfálticas; Ceniza termoeléctrica; Viabilidad económica. 


\section{Introduction}

Transportation is fundamental to the development of society. Notably, with the COVID-19 pandemic, the great importance of the referred sector is highlighted: it is essential to ensure the displacement of health professionals, as well as the distribution of pharmaceutical products and vaccines. This example shows the great need for displacement of people and goods.

In this scenario, the importance of the road modal is emphasized, which, according to Confederação Nacional do Transporte [Brazilian National Confederation of Transport] (CNT), is the most preferred by users (CNT, 2020). However, it is noteworthy that only $12.4 \%(213,453 \mathrm{~km})$ of Brazilian highways are paved, which shows the fragility of the national road network.

In the case of Amazonas, the data are even more worrying, considering that, according to CNT (2020), it is the only state in Brazil in which there are no roads with excellent or good typification, considering the general conditions of the road and the pavement. Thus, analyzing the total length of roads in Amazonas, whose amount is 1,046 km, we have the following classification: $26.9 \%$ terrible, $7.6 \%$ poor, $65.5 \%$ moderate, $0 \%$ good and excellent.

The foregoing motivates the search for new materials, which combine cost and sustainability, so verbalized nowadays, aiming to provide a longer shelf life to the pavements. In this regard, it is observed that two solid by-products are generated in thermoelectric plants: light and heavy ashes, which are harmful to the environment. Such materials cause pollution of water, air and soil (Singh, 2015). For Yang (2013), globally, power generation plants are overloaded with the problem of eliminating these wastes.

In addition, Dutta et al. (2009) mentions that the ashes are rich in oxides of $\mathrm{Si}, \mathrm{Al}, \mathrm{Fe}$ and $\mathrm{Ca}$ and small amounts of $\mathrm{K}$, $\mathrm{Mg}, \mathrm{Na}, \mathrm{Zn}, \mathrm{S}$ and N. Besides that, there is a concentration of metal ions, which can be adsorbed on the surface of the particles or in the matrix itself (Sivapullaiah \& Moghai, 2010). It is also emphasized that these materials have toxic components, such as aromatics, polycyclic hydrocarbons and heavy metals that can cause harmful effects to health. Therefore, the presence of these particles in the lungs can cause serious diseases, such as silicosis, fibrosis, bronchitis and pneumonitis, in addition to increasing the risk of cancer (Dampier, 2013). According to Calarge (2000), the residues from the combustion of mineral coal are influenced by the composition, degree of processing and grinding, handling and extraction system.

Several studies indicate great potential for the use of thermoelectric ashes in cement additives, manufacture of blocks and bricks (Calarge et al., 2000; Chies et al., 2003), special ceramic products (Ozdemir et al., 2001), fire protection panels (Vilches, 2002), erosion control (Tishmack, 2001), glass production (Erol et al., 2007) and paving (Vassilev et al., 2002; Hall, Williams, 2007).

Over the past few years, research has been intensified in order to seek alternatives to mitigate the impacts caused by human action on the environment. In this way, several economic sectors make efforts to create and develop less polluting materials aiming at replacing those currently used. Among which Engineering, which has considerable representation in the transformation of spaces and raw materials (Wang, 2020).

In particular, the road infrastructure deserves relevance, which according to Trombulak and Frissel (2000) contributes to changes in the environment, disturbances in the fauna and flora, and changes in the natural structure of the soil, as well as contributes to the contamination of the water table. In addition, the acquisition of materials for making the surface layer of pavements, such as stone aggregates (gravel) and stone dust, involves the dismantling of rocks by means of explosives that cause problems with vibration in the substrate and the release of powdery elements in the air (Bacci, 2006). In this context, research around the world has sought to include members with less environmental impact in asphalt mixtures such as industrial and organic waste (Pérez at al, 2019). 
In this prism, another material of notable interest is thermoelectric ashes, resulting from the generation of electrical energy. Therefore, they are important for the development of research aimed at the proper use of this waste, making it an important alternative in the field of paving (Tozzi, 2017).

Referring to asphalt compositions, Lehmann (2009) mentions that the use of thermoelectric ashes as a partial substitute for stone powder has presented satisfactory results, with respect to the tensile strength (TS) and the resistance module (RM). For Yang (2013), this type of alternative asphalt formulation proved to be efficient, providing tensile strength values above $1.03 \mathrm{MPa}$, recommended by the AASHTO T 283 standard. Vasudevan (2013) found that, by increasing the percentage of ash, as filler, there was an increase in the Resilience Module (RM).

However, despite the aforementioned researches aimed at analyzing the technical feasibility of using such alternative material in asphalt mixtures (Vasudevan, 2013; Yang, 2013), no publications were found on the economic feasibility of producing hot machined asphalt compositions, with the participation of thermoelectric ashes as a partial substitute for stone powder in the traditional composition.

\section{Methodology}

The main analysis consisted in obtaining and comparing the cost of producing traditional asphalt concrete (stone powder, gravel 0 , gravel 1, sand and petroleum asphalt cement) to the alternative formulation with $5.15 \%$ of thermoelectric ashes in replacement to stone powder.

The waste in the study was purchased at the thermoelectric plant of the company BK Energia, established in the municipality of Itacoatiara, Amazonas, Brazil, which uses raw material from forest management, being certified by the Forest Stewardship Council (FSC) (USEPA, 2020).

The market prices of traditional components (medium sand, stone powder, gravel no. 0, gravel no. 1 and petroleum asphalt cement) were based on the Sistema Nacional de Pesquisa de Custos e Índices da Construção Civil [National System of Research on Costs and Indices of Civil Construction] (SINAPI), managed by Caixa Econômica Federal, with the contribution of Instituto Brasileiro de Geografia e Estatística [Brazilian Institute of Geography and Statistics] (IBGE), which is responsible for the monthly update of input values. In addition, the Sistema de Custos Referenciais de Obras [Reference Construction Costs System] (SICRO), which is a responsibility of the Departamento Nacional de Infraestrutura de Transportes [National Department of Transport Infrastructure] (DNIT), was also consulted. It is noteworthy that the date base used corresponded to June 2020, as it was the most updated during the preparation of the research.

It is important to highlight that, considering that the thermoelectric ash is a waste from the generation of electric energy, the cost of this input was considered only from its transportation to the place where the asphalt mixture was made. In this way, the distance was obtained between the municipality of Itacoatiara, Amazonas, Brazil, where the company BK Energia is located, and the city of Manaus, Amazonas, Brazil. Based on this result and the SINAPI 93590 composition, expenditure was determined.

To obtain the price of the ton of the traditional asphalt concrete, a unit cost composition was elaborated based on specification 99080.3.9. of Secretaria Municipal de Infraestrutura [Municipal Secretariat of Infrastructure] (SEMINF), that is, AC machining with PAC 50/70, for bearing cover (Table 1). This formulation was selected because it is one of those used in the paving works carried out by Prefeitura Municipal de Manaus [Manaus City Hall]. 
Table 1. Base composition for obtaining the value of the ton of AC

\begin{tabular}{l|c|l|c|c}
\hline \multicolumn{1}{c|}{ Code } & Bank & \multicolumn{1}{|c}{ Description } & Unit & Quant. \\
\hline SEMINF & Own & AC machining with PAC 50/70, for bearing cover & $\mathrm{t}$ & 1.0000000 \\
\hline 88316 & SINAPI & Servant with additional charges & $\mathrm{h}$ & 0.1067000 \\
\hline 5944 & SINAPI & Wheel loader, power of 197 HP, bucket capacity of 2.5 to $3.5 \mathrm{~m}^{3}$ & CHP & 0.0035000 \\
\hline 7030 & SINAPI & Stationary asphalt tank with serpentine & CHP & 0.0134000 \\
\hline 93433 & SINAPI & Hot asphalt mixing plant, counter flow type & CHP & 0.0134000 \\
\hline 0000370 & SINAPI & Medium sand & $\mathrm{m}^{3}$ & 0.1610000 \\
\hline SEMINF & Own & PAC 50/70 & $\mathrm{kg}$ & 60.0000000 \\
\hline 0001379 & SINAPI & Portland cement compound CP II-32 & $\mathrm{kg}$ & 28.0000000 \\
& & & $\mathrm{~m}^{3}$ & 0.3129000 \\
\hline 0004720 & SINAPI & Gravel n. 0, ou pebble $(4.8$ a $9.5 \mathrm{~mm})$ & $\mathrm{m}^{3}$ & 0.1341000 \\
\hline 0004721 & SINAPI & Gravel n. 1 (9.5 a $19 \mathrm{~mm})$ & & \\
\hline
\end{tabular}

Abbreviations: CHP = Productive Hourly Cost. Source: Authors.

It should be noted that composition 99080.3.9 SEMINF has been adapted to the aforementioned inputs. In view of this, Portland cement, one of the components, was replaced by the stone powder used in the reference dosage. At this juncture, the specific masses of the materials that make up the standard formulation were used in the calculation of the coefficients (medium sand, PAC 50/70, stone powder, gravel no. 0 and gravel no. 1).

In addition, the transportation of inputs to the place of production of the asphalt mixture was added. In this case, the auxiliary composition SINAPI Code 93590, whose unit is $\mathrm{m}^{3} \mathrm{x} \mathrm{km}$, is included. This amount was calculated based on the production of one (01) ton of $\mathrm{AC}$ and the average distance of the quarries and sandy deposits nearest to the city of Manaus, Amazonas, Brazil.

The replacement of stone powder with ashes from a thermoelectric plant in the proportion of $5.15 \%$ was also considered for the alternative composition, considering that it is the most appropriate proportion according to Yang (2013), as well as the freight to the final value of these asphalt formulations.

\section{Results and Discussion}

The prices of inputs corresponding to medium sand, stone powder, petroleum asphalt cement (PAC), gravel 0 and gravel 1, were obtained in accordance with the SINAPI price list for the State of Amazonas, with a base date of June 2020 (Table 2).

Table 2. Unit value, according to SINAPI, for Amazonas, in June 2020.

\begin{tabular}{c|c|c}
\hline Materials & Unit & Unit Value (R\$) \\
\hline Medium Sand & $\mathrm{m}^{3}$ & 75.00 \\
\hline Sand Powder & $\mathrm{m}^{3}$ & 89.12 \\
\hline PAC & $\mathrm{t}$ & $2,658.96$ \\
\hline Gravel 0 & $\mathrm{m}^{3}$ & 119.21 \\
\hline Gravel 1 & $\mathrm{m}^{3}$ & 93.36 \\
\hline
\end{tabular}

Source: Authors.

The cost of the waste resulted essentially from the transportation of the material, that is, from the place where it was obtained, the BK Energia thermoelectric plant located in the municipality of Itacoatiara, Amazonas, to the city of Manaus, 
Amazonas. Thus, for the calculation of the cost of this displacement, the distance of $240 \mathrm{~km}$ and the composition SINAPI 93590 (Transportation with $10 \mathrm{~m}^{3}$ Dump Truck, on paved urban road, ATD [average transport distance] over $30 \mathrm{~km}$ ) were considered.

In addition, a coefficient of $2.568 \mathrm{~m}^{3} \mathrm{x} \mathrm{km}$ (cubic meters per kilometer) was obtained, which resulted from the replacement of $5.15 \%$ of thermoelectric ash from the total amount corresponding to the stone powder conventionally used in the production of 01 ton of asphalt mixture, that is, the value of $0.2075 / \mathrm{m}^{3}$ (cubic meters), as well as the distance of $240 \mathrm{~km}$. Therefore, taking into account the SINAPI 93590 composition of $\mathrm{R} \$ 0.67 / \mathrm{m}^{3} \mathrm{x} \mathrm{km}$, the amount of $\mathrm{R} \$ 1.72$ (Equations 1,2 and 3) was determined.

$$
\begin{aligned}
0.2075 \mathrm{~m}^{3} \times 0.0515 & =0.0107 \mathrm{~m}^{3} \\
0.0107 \mathrm{~m}^{3} \times 240 \mathrm{~km} & =2.568 \mathrm{~m}^{3} \times \mathrm{km} \\
2.568 \times R \$ 0.67 & =R \$ 1.72
\end{aligned}
$$

The composition for the Asphalt Concrete (AC) Machining service for bearing cover (reference) was elaborated, based on the formulation 99080.3.9.SEMINF. The following materials were used: Medium sand, gravel n. 0 , gravel no. 1 and stone powder, and PAC 50/70 (Figure 1).

Figure 1. Quantity of materials considering the reference dosage.

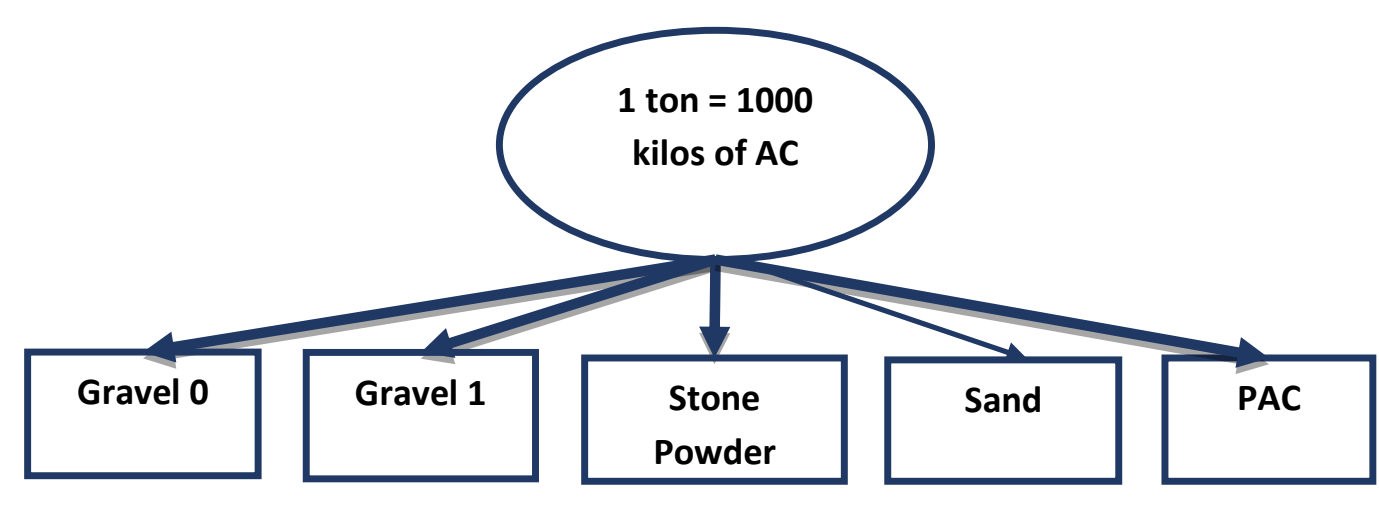

Source: Authors.

The coefficients were adapted through the conversion of units and in accordance with the production of 01 ton of AC. In view of this, in the case of gravel 0 , gravel 1 , stone powder and sand, the weight of each material was divided by the respective specific mass, with results in $\mathrm{m}^{3}$ (cubic meters). For the PAC, the value for tons was modified using the factor 1000 $\mathrm{kg} / \mathrm{t}$ (kilogram per ton). This procedure resulted in the adapted formulation (99080.3.9. SEMINF - ADAPTED), recorded in Table 3. 
Table 3. Composition of Unit Costs (CCU) adapted to reference materials and respective coefficients.

\begin{tabular}{c|c|l|c|c|c|c}
\hline Code & Bank & \multicolumn{1}{|c|}{ Description } & Unit & Quant. & $\begin{array}{c}\text { Unit } \\
\text { Value }\end{array}$ & Total \\
\hline $\begin{array}{c}\text { 99080.3.9.seminf - } \\
\text { adapted }\end{array}$ & Own & $\begin{array}{l}\text { AC machining with PAC 50/70, } \\
\text { for bearing cover }\end{array}$ & $\mathrm{t}$ & 1.0000000 & 224.09 & 224.09 \\
\hline 88316 & SINAPI & Servant with additional charges & $\mathrm{h}$ & 0.1067000 & 16.37 & 1.74 \\
\hline 5944 & SINAPI & Wheel loader & CHP & 0.0035000 & 141.36 & 0.49 \\
\hline 7030 & SINAPI & $\begin{array}{l}\text { Stationary asphalt tank with } \\
\text { serpentine }\end{array}$ & CHP & 0.0134000 & 124.08 & 1.66 \\
\hline 93433 & SINAPI & Hot asphalt mixing plant & $\mathrm{CHP}^{3}$ & 0.0134000 & $1,810.69$ & 24.26 \\
\hline 00000370 & SINAPI & Medium sand & $\mathrm{m}^{3}$ & 0.1793000 & 75.00 & 13.44 \\
\hline 00004720 & SINAPI & $\begin{array}{l}\text { Gravel n. 0, ou pebble }(4.8 \text { a } 9.5 \\
\text { mm) }\end{array}$ & $\mathrm{m}^{3}$ & 0.1847000 & 119.21 & 22.01 \\
\hline 00004721 & SINAPI & Gravel n. 1 (9.5 a 19 mm) & $\mathrm{m}^{3}$ & 0.0971000 & 93.36 & 9.06 \\
\hline 00004741 & SINAPI & Stone powder & $\mathrm{m}^{3}$ & 0.2075000 & 89.12 & 18.49 \\
\hline 00041899 & SINAPI & Petroleum asphalt cement 50/70 & $\mathrm{t}$ & 0.0500000 & $2,658.96$ & 132.94 \\
\hline & & \multicolumn{2}{|l|}{ Value with BDI => } & 224.09 \\
\hline
\end{tabular}

Source: Authors.

Subsequently, the financial consumption of the transportation of inputs to the place of asphalt mixture production was added, using auxiliary compositions contained in SINAPI 93590 and SINAPI 93177, alluding to aggregates and petroleum asphalt cement (PAC 50/70), respectively. The calculations referring to SINAPI 93590 were supported by the average distance of the quarries and sandy deposits nearest to Manaus, Amazonas (Table 4).

Table 4. Average distance from locations of material acquisition to central Manaus.

\begin{tabular}{c|c}
\hline Materials & Average Distance \\
\hline Stone Powder & $135 \mathrm{~km}$ \\
\hline Gravel 0 & $135 \mathrm{~km}$ \\
\hline Gravel 1 & $135 \mathrm{~km}$ \\
\hline Sand & $30 \mathrm{~km}$ \\
\hline PAC 50/70 & $15 \mathrm{~km}$ \\
\hline
\end{tabular}

Source: Authors.

When carrying out the calculations, initially, the coefficients related to the materials whose acquisition could be carried out at $135 \mathrm{~km}$ were added, among which, stone powder, gravel 0 and gravel 1, resulting in the value of 0.4893 . Then, it was multiplied by the distance, resulting in $66.0555 \mathrm{~m} 3 \mathrm{x} \mathrm{km}$ (cubic meters per kilometer). In the case of sand, whose index was equal to 0.1793 , it was multiplied by $30 \mathrm{~km}$, obtaining 5.379. At the end, results were added (66.0555 and 5.379), making it possible to determine the value of $71.434 \mathrm{~m}^{3} \mathrm{x} \mathrm{km}$ (cubic meters per kilometer), which refers to the amount of composition 93590.

The regulation by SINAPI 93177 (Transportation of asphalt material with a 20000 L capacity truck on a paved road for average transportation distances equal to or less than $100 \mathrm{~km}$ ) was observed. In this situation, the PAC's 0.05 coefficient was multiplied by the distance of $15 \mathrm{~km}$, resulting in the value of $0.75 \mathrm{~m}^{3} \mathrm{x} \mathrm{km}$. Table 5 shows the adapted formulation. Quantifying the production of 1 ton of AC plus the transportation of inputs to the asphalt mixing plant resulted in R 273.18 . This value indicated that there was an increase of $21.91 \%$ to that without transportation. 
Table 5. Composition of Unit Costs (CCU) for the transportation of inputs to the place of asphalt mixture production.

\begin{tabular}{|c|c|c|c|c|c|c|}
\hline Code & Bank & Description & Unit & Quant. & $\begin{array}{c}\text { Unit } \\
\text { Value }\end{array}$ & Total \\
\hline $\begin{array}{l}\text { 99080.3.9.seminf } \\
\text { - adapted - transp. }\end{array}$ & Own & AC machining with PAC 50/70 & $\mathrm{t}$ & 1.0000000 & 273.18 & 273.18 \\
\hline 88316 & SINAPI & Servant with additional charges & $\mathrm{h}$ & 0.1067000 & 16.37 & 1.74 \\
\hline 5944 & SINAPI & Wheel loader & $\mathrm{CHP}$ & 0.0035000 & 141.36 & 0.49 \\
\hline 7030 & SINAPI & Stationary asphalt tank & $\mathrm{CHP}$ & 0.0134000 & 124.08 & 1.66 \\
\hline 93433 & SINAPI & Hot asphalt mixing plant & CHP & 0.0134000 & $1,810.69$ & 24.26 \\
\hline 93590 & SINAPI & $\begin{array}{l}\text { Transportation with a } 10 \mathrm{~m}^{3} \text { dump } \\
\text { truck }\end{array}$ & $\begin{array}{c}\mathrm{m} 3 \mathrm{x} \\
\mathrm{km}\end{array}$ & 71.434000 & 0.67 & 47.86 \\
\hline 93177 & SINAPI & $\begin{array}{l}\text { Transportation of asphalt } \\
\text { material, with a } 20000 \text { L capacity } \\
\text { truck }\end{array}$ & $\begin{array}{l}\mathrm{tx} \\
\mathrm{km}\end{array}$ & 0.7500000 & 1.65 & 1.23 \\
\hline 00000370 & SINAPI & Medium sand & $\mathrm{m}^{3}$ & 0.1793000 & 75.00 & 13.44 \\
\hline 00004720 & SINAPI & $\begin{array}{l}\text { Gravel n. } 0 \text {, ou pebble }(4.8 \text { a } 9.5 \\
\mathrm{mm})\end{array}$ & $\mathrm{m}^{3}$ & 0.1847000 & 119.21 & 22.01 \\
\hline 00004721 & SINAPI & Gravel n. 1 (9.5 a 19 mm) & $\mathrm{m}^{3}$ & 0.0971000 & 93.36 & 9.06 \\
\hline 00004741 & SINAPI & Stone powder & $\mathrm{m}^{3}$ & 0.2075000 & 89.12 & 18.49 \\
\hline 00041899 & SINAPI & Petroleum asphalt cement 50/70 & $\mathrm{t}$ & 0.0500000 & $2,658.96$ & 132.94 \\
\hline & & & & \multicolumn{2}{|c|}{ Value with BDI $=>$} & 273.18 \\
\hline
\end{tabular}

Abbreviations: $\mathrm{CHP}=$ Productive Hourly Cost. Source: Authors.

In order to compare with the value of $\mathrm{AC}$ containing the alternative material thermoelectric ash as a partial substitute $(5.15 \%)$ for stone powder, our own composition aforementioned was again modified. In this case, the coefficients of inputs of the traditional formulation were added, however with a change in the amount of stone powder to $0.1968 \mathrm{~m}^{3}$. The difference in the order of $0.01068 \mathrm{~m}^{3}$ (cubic meters per kilometer) was multiplied by $240 \mathrm{~km}$, which corresponded to the distance between the location where the thermoelectric ash was acquired and the city of Manaus, Amazonas, Brazil. Subsequently, the sum was carried out, resulting in the value of $72.5547 \mathrm{~m}^{3} \mathrm{x} \mathrm{km}$ referring to the new quantity of the SINAPI 93590 service. The final value of the AC with thermoelectric residue was $\mathrm{R} \$ 272.97$, as seen in Table 6. 
Table 6. Composition of Unit Costs (CCU) considering the alternative input thermoelectric ash.

\begin{tabular}{|c|c|c|c|c|c|c|}
\hline Code & Bank & Description & Unit & Quant. & $\begin{array}{c}\text { Unit } \\
\text { Value }\end{array}$ & Total \\
\hline $\begin{array}{l}\text { 99080.3.9.seminf - } \\
\text { adapted - therm. } \\
\text { ashes }\end{array}$ & Own & $\begin{array}{l}\text { AC machining with PAC 50/70 } \\
\text { and thermoelectric ashes - with } \\
\text { transportation of inputs }\end{array}$ & $\mathrm{t}$ & 1.0000000 & 272.97 & 272.97 \\
\hline 88316 & SINAPI & Servant with additional charges & $\mathrm{h}$ & 0.1067000 & 16.37 & 1.74 \\
\hline 5944 & SINAPI & Wheel loader & CHP & 0.0035000 & 141.36 & 0.49 \\
\hline 7030 & SINAPI & Stationary asphalt tank & CHP & 0.0134000 & 124.08 & 1.66 \\
\hline 93433 & SINAPI & Hot asphalt mixing plant & CHP & 0.0134000 & $1,810.69$ & 24.26 \\
\hline 93590 & SINAPI & $\begin{array}{l}\text { Transportation with a } 10 \mathrm{~m}^{3} \\
\text { dump truck }\end{array}$ & $\mathrm{m} 3 \times \mathrm{km}$ & 72.554700 & 0.67 & 48.61 \\
\hline 93177 & SINAPI & $\begin{array}{l}\text { Transportation of asphalt } \\
\text { material, with a } 20000 \mathrm{~L} \\
\text { capacity truck }\end{array}$ & $\mathrm{t} \times \mathrm{km}$ & 0.7500000 & 1.65 & 1.23 \\
\hline 00000370 & SINAPI & Medium sand & $\mathrm{m}^{3}$ & 0.1793000 & 75.00 & 13.44 \\
\hline 00004720 & SINAPI & $\begin{array}{l}\text { Gravel n. } 0 \text {, ou pebble ( } 4.8 \text { a } 9.5 \\
\text { mm) }\end{array}$ & $\mathrm{m}^{3}$ & 0.1847000 & 119.21 & 22.01 \\
\hline 00004721 & SINAPI & Gravel n. $1(9.5$ a $19 \mathrm{~mm})$ & $\mathrm{m}^{3}$ & 0.0971000 & 93.36 & 9.06 \\
\hline 00004741 & SINAPI & Stone powder & $\mathrm{m}^{3}$ & 0.1968000 & 89.12 & 17.53 \\
\hline 00041899 & SINAPI & Petroleum asphalt cement 50/70 & $\mathrm{t}$ & 0.0500000 & $2,658.96$ & 132.94 \\
\hline & & & & \multicolumn{2}{|c|}{ Value with BDI $=>$} & 272.97 \\
\hline
\end{tabular}

Abbreviations: CHP = Productive Hourly Cost. Source: Authors.

The values of Asphalt Concrete (AC) of the traditional asphalt mixture and the alternative formulation were $\mathrm{R} \$$ 273.18 and $\mathrm{R} \$ 272.97$, respectively. There was a saving of $\mathrm{R} \$ 0.21$ per ton of AC machining with PAC 50/70, with thermoelectric ash as a partial substitute $(5.15 \%)$ for stone powder, representing a reduction of $0.077 \%$ per ton. However, the closer the plant's distance and the higher the percentage, the greater are the benefits.

\section{Conclusion}

The economic viability of the production of hot machined asphalt mixtures was analyzed, containing thermoelectric ashes as a partial substitute for stone powder.

That said, the cost of a ton of the reference formulation was compared to that containing a share of the new input. Savings of R $\$ 0.21$ per ton were achieved when $5.15 \%$ of stone powder were replaced by thermoelectric ashes, representing $0.0077 \%$ of savings per ton.

From the above, it can be concluded that the use of thermoelectric residue in asphalt formulations is economically viable. Finally, it is emphasized that the use of this material is recent in researches on paving. Thus, it is suggested for future studies to carry out the mechanical characterization by flexing apparatus at 04 points and the use of new thermoelectric ash contents, such as $10 \%$ and $12 \%$.

\section{References}

Bacci, D. L. C. (2006). Aspectos e impactos ambientais de pedreira em área urbana. Esc. Minas, 59.

Confederação Nacional dos Transportes - CNT. (2020). Anuário CNT. https://anuariodotransporte.cnt.org.br/2020. 
Dampier, J. E. E., Shahi, C., Lemelin, R. H. et al. (2013). From coal to wood thermoelectric energy production: a review and discussion of potential socioeconomic impacts with implications for Northwestern Ontario, Canada. Energ Sustain Soc 3, 11. https://doi-org.ez2.periodicos.capes.gov.br/10.1186/21920567-3-11.

Dutta, B. K., Khanra, S. E., \& Mallick, D. (2009). Lixiviação de elementos a partir de cinzas volantes de carvão: Avaliação de seu potencial para uso em envase minas de carvão abandonadas. Combustível, 88 (7), 1314-1323.

Erol, M., Küçükbayrak, S., \& Ersoy-Meriçboyu, A. (2007) Characterization of coal fly ash for possible utilization in glass production. Fuel 706 - 714.

Hall W., Williams P. (2007). Separation and recovery of materials from scrap printed circuit boards. Resour Conserv Recycl 51:691-709.

Ozdemir, O., Ersoy, B., \& Celil, M. S. (2001). Separation of pozzolanic materials from lignitic fly ash of Tuncbilek Power Station. In: Internacional Ash Utilization Symposium, 4, Lexington, Kentucky, USA, Proceedings, University of Kentucky, p. 216 - 234.

Lehmann, J., \& Joseph, S. (2009). Biochar for environmental management. Science and technology, Earthscan. 1-12.

Pérez, I. P. Pasandin, A. M. R., Pais, J. C. \& Pereira, P. A. A. (2019). Use of lignina biopolymer from industrial waste as bitumen extender for asphalt mixtures. Journal of Cleaner Production.

Singh, M. (2015). Effect of coal bottom ash on strength and durability properties of concrete. Punjab Thesis (ph. D. Civil Engineering) -Thapar University, India, 2015

Sivapullaiah, P. V. \& Moghal, A. A. B. (2010). Lixiviação de rastreamento elementos de duas cinzas volantes indianas estabilizadas de baixo cal. Environ. Terra Sci. 61 (8), 1735-1744.

Tishmack, J .K. (2001). Use of coal combustion by-products to reduce soil erosion. In: Internacional Ash Utilization Symposium, 4, Lexington, Kentucky, USA, Proceedings, University of Kentucky, 216-234.

Tozzi, L. P. (2017). Reciclagem de Placas de Circuito Impresso para Obtenção de Metais Não Ferrosos. Trabalho de Conclusão de Curso apresentado na Universidade Tecnológica Federal do Paraná.

Trombulak, S. C., \& Fissell, C. A. (2000). Review of ecological effects of roads on terrestrial and aquatic communities. Conservation Biology, 14, 18-30.

USEPA (Agência de Proteção Ambiental dos EUA). (2020). Humano e avaliação de risco ecológico de resíduos de combustão de carvão.

Vasudevan, S. (2013). Multicomponent utilization of fly ash: dream or reality. In: International Ash Utilization Symposium, 4, Lexington, Kentucky, USA, Proceedings, University of Kentucky, p. $216-234$.

Vassilev, S. V., Menendez, R., Alvarez, D., \& Borrego, A. G. (2002). Multicomponent utilization of fly ash: dream or reality. In: International Ash Utilization Symposium, 4, Lexington, Kentucky, USA, Proceedings, University of Kentucky, 216 - 234.

Vilches, L. F. (2002). Development of new fire-proof products made from coal fly ash: the Cefyr Project. Journal of Chemical Technology and Biotechnology, $77,361-366$.

Wang, H., Derewecki, K. (2020). Rheological Properties of Asphalt Binder Partially Substituted with Wood Lignin. In: Airfield and Highway Pavement: Sustainable and Efficient Pavements. 977-986.

Yang, C, Mills-Beale, J., \& You, Z. (2013). Chemical characterization and oxidative aging of bio-asphalt and its compatibility with petroleum asphalt. Journal of Cleaner Production, 142, 1837-1846. 